International Journal of Agriculture and Environmental Research

ISSN: 2455-6939

Volume: 06, Issue: 06 "November-December 2020"

\title{
COMPETITIVENESS OF NIGERIAN CASHEW NUTS EXPORTS IN THE GLOBAL MARKET
}

\author{
Oni Timothy Olukunle. \\ Department of Agriculture and Food Policy, Nigerian Institute of Social and Economic Research \\ (NISER), P.M.B 5, U.I. Post Office, Ojoo, Oyo Road, Ibadan, Nigeria. \\ DOI: https://doi.org/10.51193/IJAER.2020.6612
}

\begin{abstract}
In Nigeria, cashew is an important contributor to the Gross Domestic product (GDP) and significant source of non-oil foreign exchange earnings for the country. Over the past three decades, cashew nut alone has contributed an annual average of US\$253.25 million to GDP of the country. However, the industrial investment potentials of the export crop are yet to be fully exploited due to inadequate value addition to the primary product in the country which has constrained competitiveness of the export crop in the global market. Therefore, the paper evaluates the determinants of the competitiveness of the product in the world market. Secondary time series data covering 37 years from 1980 to 2017 were used. Augmented Dickey Fuller Statistics, autoregressive distributed lag model and error correction mechanism were used in the analysis of data. Significant determinants of competitiveness of exports of cashew nuts indicate the need for efficiency in spending on infrastructure development. This should be focused on improving electricity consumption from public supply for ease of processing. Transportation system, repair of old damaged roads and building of new ones should link village to village and village to industrial centres, as well as linking village to urban towns and ports for ease of logistics in moving the export product to the global market.
\end{abstract}

Keywords: Cashew, Competitiveness, Export, Infrastructure, Market, Research.

\subsection{INTRODUCTION}

Nigeria is one of the important countries that produce cashew nuts worldwide. Over the period, 1980 to 2018, Nigeria's annual production of cashew recorded an annual average of 251.24 thousand tonnes (Table 1 and Figure 1). This is approximately $10 \%$ of the world's average production of cashew. The world average annual production of cashew was 2.13 million tonnes, during the same period (Food and Agriculture organization (FAO database accessed, 2020. Cashew nut is a significant contributor to the economic growth in Nigeria. Over the past three 
Volume: 06, Issue: 06 "November-December 2020"

decades, cashew nut alone has contributed an annual average of US\$253.25 million to the Gross Domestic Product (GDP) of Nigeria (FAO database, 2019). Cashew has tremendous potential as a cash crop to generate foreign exchange and to create employment especially for women as well as curb desertification in Northern Nigeria and erosion in the Southern Nigeria (Alawode and Adeniranye, 2020). The crop has high investment and export potentials. Exports recorded an annual average amount of US\$33.10 million for the product over the same period (Table1). Contribution of cashew nuts to foreign exchange earnings between 1980 and 2018has recorded an annual average growth rate of133.16 per cent (FAO database, 2020). Stable market exists locally and

Table 1: Average Production and Export of Nigerian Cashew.

\begin{tabular}{lccccc}
\hline \multicolumn{1}{c}{ Period } & $\begin{array}{c}\text { Area Planted } \\
\text { in '000Ha }\end{array}$ & Yield in Kg/Ha & $\begin{array}{c}\text { Output in } \\
\text { '000tonnes }\end{array}$ & $\begin{array}{c}\text { Export Quantity } \\
\text { in '000tones }\end{array}$ & $\begin{array}{c}\text { Export Value in } \\
\text { Million US\$ }\end{array}$ \\
\hline $1980-85$ & 40.00 & 625.00 & 25.00 & 0.87 & 0.36 \\
$1986-90$ & 42.00 & 620.00 & 26.00 & 7.66 & 4.21 \\
$1991-95$ & 115.00 & 615.72 & 71.00 & 13.66 & 7.00 \\
$1996-2000$ & 231.64 & $1,063.86$ & 254.00 & 2.95 & 2.40 \\
$2001-2005$ & 283.20 & $1,885.54$ & 534.40 & 16.41 & 8.24 \\
$2006-2010$ & 344.50 & $2,065.16$ & 712.60 & 16.15 & 9.65 \\
$2011-2015$ & 211.68 & $1,146.64$ & 272.83 & 56.26 & 118.50 \\
$2016-2018$ & 61.05 & $1,341.23$ & 98.10 & 52.65 & 161.35 \\
$1980-2018$ & 170.24 & $1,168.09$ & 251.24 & 20.68 & 33.10 \\
\hline
\end{tabular}

Source: FAOSTAT, 2020. 


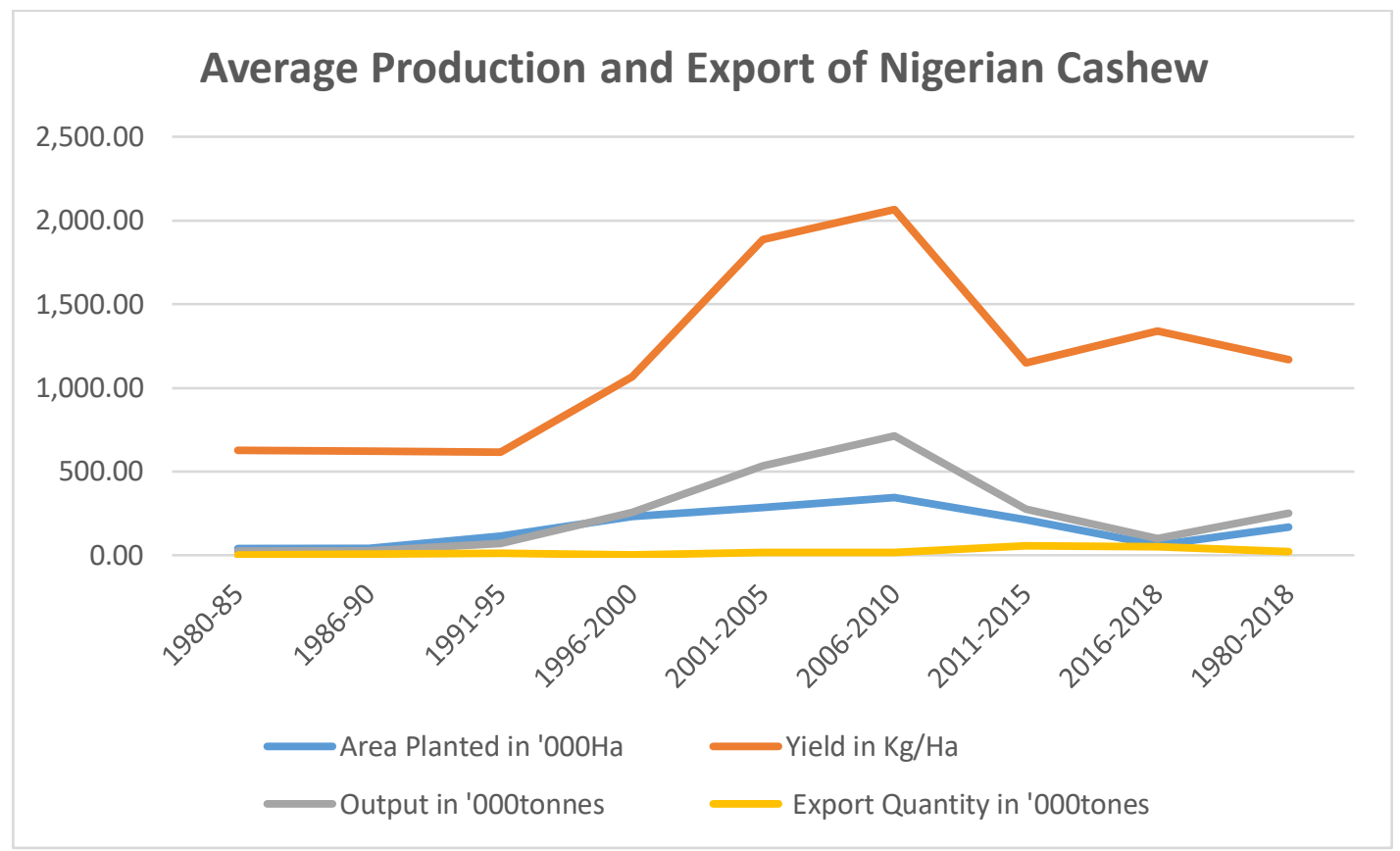

Source: Underlying data collected from FAOSTAT, 2020.

Figure 1: Line graph of Average Annual Production and Export of Nigerian Cashew.

Internationally for the product and it attracts international visibility to Nigeria apart from being important raw material for local industries (Chemonics International, 2002). Similarly, there is growing demand for good quality cashew domestically and internationally. Interest among cashew companies to expand their processing capacity is growing and the commodity has strong potential for employment creation and all the agro-ecological zones have highly supportive soil and climate for cashew production (Olawale and Akinkunle, 2018).

However, Nigeria now faces several challenges in the effort to improve its cashew production. Many existing cashew trees have reached the end of their productive cycles and the majority that still bear fruit produce small nuts of low value. Unimproved planting materials, aging trees and low yields are part of the production constraints of raw cashew nut in the country (Adeigbe et al, 2015). Cashew industry in Nigeria focuses on low end raw nut production losing substantial income to other countries such as India and Vietnam by not improving on value added products due to low processing. Moreover, Nigeria receives the lowest international prices in Africa for its raw nuts due to low quality of production, inadequate processing and poor post-harvest handling. (Chemonics 2002).Huge post-harvest losses usually occurred during harvesting period. Processing and transformation through improved technology for obtaining a diversified high valued product from raw cashew remained abysmally constrained and limited resulting into low 
International Journal of Agriculture and Environmental Research

ISSN: 2455-6939

Volume: 06, Issue: 06 "November-December 2020"

commercial and industrial utilization of cashew in Nigeria. Industrial exploitation of the crop has been neglected for a long time in favour of oil production which has left Nigeria behind in competing for the global cashew market (Olawale and Akinkunle, 2018).

Since more than half of the population in Nigeria resides in rural areas and most of the rural households in the country are dependent on agriculture where they derive about three-quarter of their income, the potentials of cashew for income and employment generation at the different stages of its value chain need to be fully exploited to contribute meaningfully to livelihoods of rural population and to optimally exploit the growth potentials of the crop for economic growth of Nigeria. Improved competitiveness of exports of cashew products will impact substantially on export growth and export growth would in turn generate cash income for modernizing agricultural practices which ultimately would create more jobs in agricultural processing and marketing as well as expanding agro-processing industries and other non-farm jobs. In the light of the foregoing, export growth in the cashew subsector will play a crucial role in overall development, especially by driving economic growth, creating jobs, and providing an important source of foreign exchange. Moreover, a sound knowledge and understanding of determinants of revealed competitive advantage of cashew in the world market is vitally important if the growth and employment generating prospects in the export commodity would be fully exploited. The study is therefore prompted by the need to generate information that could guide policy modification and implementation in revitalizing cashew industry in Nigeria. Therefore, the objective of the paper is to evaluate the competitiveness of cashew nuts exports in the world market using revealed competitive advantage indicator and to assess the major determinants of the competitiveness of the product in the world market. This is necessary in order to offer useful policy measures to improve production and competitiveness of the product in the global market for increased foreign exchange earnings as well as to generate more employment in the cashew value chain in Nigeria. The paper is structured into four sections. Following this introductory section is section two which concentrates on research design and methodology adopted. Section three discusses the major results while the paper is rounded off in section four with policy recommendations and conclusion.

\subsection{METHODOLOGY}

\subsection{Types, sources and measurement of data}

Time series secondary data were used for the study from which the paper emerged. The study data were obtained from the databases of Food and Agriculture Organization (FAOSTAT), Central Bank of Nigeria (CBN), National Bureau of Statistics (NBS), International Food Policy Research Institute (IFPRI), Agricultural Science and Technology Indicators (ASTI), United Nations Conference on Trade and Development (UNCTAD), and World Development 
International Journal of Agriculture and Environmental Research

ISSN: 2455-6939

Volume: 06, Issue: 06 "November-December 2020"

Indicators, by the World Bank. Data extracted included Nigeria's export value of cashew nuts, Nigeria's export of goods and services, Nigerian import value of cashew nuts, World's agricultural exports, World's export of goods and services, Nigeria's agricultural import value, Nigeria's imports of goods and services, world's agricultural imports and the world's import of goods and services, all measured in United States' Dollar Equivalent (US\$). In addition, the study data comprised of Gross fixed capital formation in agriculture in Nigeria in US\$, Agricultural Researchers with MSc/Ph.D. as a percentage share of total agricultural researchers, and official exchange rate, in naira per US\$, Foreign direct investment in agriculture in US\$. Other data used included government total spending on road construction and maintenance in real terms in US\$, Electricity power consumption from public provision in kilowatt hour per capita, world market price of cashew in dollar per tonne, and interest rate on agricultural lending. The dataset covered 37 years from 1980 to 2017, which satisfy the econometric properties of a large sample size required for the estimate of the determinants of export competitiveness of cashew using co-integration and autoregressive distributed lag (ARDL) regression Technique.

\subsection{Analytical Framework}

At the first stage of the analysis, Revealed Competitive Advantage of Cashew (RCACA) was computed and described using descriptive statistics such as averages and coefficient of variations. This is followed by time series analysis of data using Augmented Dickey Fuller (ADF) Statistics. Finally, cointegration and error correction model was estimated using Autoregressive Distributed Lag (ARDL) technique to analyse the determinants of competitiveness of cashew export product. Revealed Competitive Advantage (RCA) index is calculated for the export of cashew nuts using the model in equations 2.1, 2.2 and 2.3 which was adapted from (Vollrath, 1987, 1991).

RCAi,ag $=$ RCS $_{i, \text { ag }}-$ RCDi,ag .

Where $\mathrm{RCS}_{\mathrm{i}, \mathrm{ag}}=\left[\left(\mathrm{X}_{\mathrm{i}, \mathrm{ag}} / \mathrm{X}_{\mathrm{i}, \mathrm{gs}}\right) /(\mathrm{Xw}, \mathrm{ag} / \mathrm{Xw}, \mathrm{gs})\right]$

$\mathrm{RCD}_{\mathrm{i}, \mathrm{ag}}=\left[\left(\mathrm{Mi}, \mathrm{ag} / \mathrm{M}_{\mathrm{i}}, \mathrm{gs}\right) /(\mathrm{Mw}, \mathrm{ag} / \mathrm{Mw}, \mathrm{gs})\right]$

$\mathrm{RCS}_{\mathrm{i}}$, ag refers to Nigeria's Revealed Comparative Supply of agricultural export, with $\mathrm{X}_{\mathrm{i}}$, ag referring to the country i's export value (cashew), $X_{\mathrm{i},}$ gs refers to the country's export of goods and services, $\mathrm{Xw}$, ag refers to the world agricultural export value (cashew) and $\mathrm{Xw}$, gs refers to the world export of goods and services.

$\mathrm{RCD}_{\mathrm{i}}$ ag refers to revealed comparative demand for agricultural product with $\mathrm{Mi}$, agrelating to the country's agricultural import value (cashew), $\mathrm{M}_{\mathrm{i}}$, gs relating to the country's import of goods and services. Mw, ag refers to the world's agricultural import(cashew), and Mw, gs refers to the world's imports of goods and services. The difference between $R C S_{i}$ ag and $R C D_{i}$, ag measures 
International Journal of Agriculture and Environmental Research

ISSN: 2455-6939

Volume: 06, Issue: 06 "November-December 2020"

net relative trade shares and is called revealed competitive advantage (RCAi, ag) [Vollrath, T.L. 1987, 1991].

Conceptually, quantitative indicator of revealed competitive advantage (RCA) contains two comparisons. Firstly, is comparison between two trading entities, Nigeria and the World, and secondly, is comparison between two commodities, agricultural export commodity and all goods and services. RCA coefficients are largely determined by economic factors such as resource endowments, technology and income (Vollrath, T.L.1987, 1991). The indicator, RCA, summarize how a country or region has performed in commodity trade, thus it is a better indicator of competitiveness than of the comparative advantage. Nigerian Agricultural export is expected to be influenced by investments in Research and Development and human capital that induce changes in agricultural production. This result into efficient utilization of other inputs. Export competitiveness requires large investment in research and development, advanced technology, high quality infrastructure and close interactions between firms and research institutes (Zhang, 2015). From this point of view, in this paper, a set of variables including physical capital, research and development, infrastructure, and foreign direct investment (FDI) inflows are variables that are theoretically expected to influence the competitive advantage of Nigeria cashew exports in the global market. This will ultimately impact positively on the country's economic development. As a stock of physical capital increases, a country experiences capital deepening which provides for a more productive labor force which will eventually enhance product upgrading.

Capacity and technology of industry depends on the availability and quality of infrastructure, ranging from roads and ports to telecommunication. Poor transport and communications infrastructure isolate countries, limiting their participation in global economy (Gonul $\mathrm{M}$ and Yusuf M, 2016). Similarly, domestic technological effort is an important determinant of both quality (exports upgrading) and quantity (exports capacity) which highlights the importance of domestic Research and Development (R\&D). R\&D efforts lead to successful innovations; new products drive and the acquisition of export market shares. Strong R\&D efforts enhance competitive advantage.

So, in analyzing the determinants of competitiveness of Nigerian cashew exports in the global market, the following model is used to achieve this objective. The model is adapted from Zhang 2015. This is specified and estimated for Revealed competitive advantage of cashew exports.

\subsection{Empirical Model Specification}

The model is specified as: 
rcaca $_{i t}=\beta_{0}+\beta_{1} f d i_{i t}+\beta_{2} g f c f_{i t}+\beta_{3}$ lint $_{i t}+\beta_{4} E X H R+\beta_{5} r d_{i t}+\beta_{6}$ Infra $_{i t}+$ $\beta_{7} T f r e_{i t}+\beta_{8} W P+\varepsilon_{i t}$

Where rcaca is revealed competitive advantage indicator for cashew exports, fdi is foreign direct investment, gfcf is gross fixed capital formation, lint is bank's lending interest rate, rd is the variable for research and development. EXHR is exchange rate, Infra is infrastructure variable for road, telecommunication and communication and electricity consumption per capita, Tfr is tariff rate, WP is world market price, $\beta_{0}$ is the constant and $\varepsilon_{i t}$ is the error term of the model.

\subsection{RESULTS AND DISCUSSION}

\subsection{Trend in Domestic Production of Cashew Nuts}

Domestic production of cashew nuts witnessed consistent increase since 1980 till 2000 as can be seen in Table 2. This result can be attributed to farmer's response to rising international market price of cashew nuts and adoption of improved production practices (Alawode and Adeniranye 2020). As shown in table 2, the improved production practices have led to substantial increase in the growth rate of the yield of the export crop in 1996-2000 sub-period when the average annual growth rate of the yield of the crop was about 38 percent during the sub-period. The highest average annual growth rate of 47.42 percent was attained in the production of cashew in the country in the 1996-2000 sub-period, thereafter the growth rate of production declined to average of 4.99 per cent in the 2001-2005 sub-period. The growth rate of the production recovered the increase again in the sub-period 2006-2010 with an average annual growth rate of 6.12 percent. This was due to the significant expansion in the area planted to the export crop in the 2006-2010 sub-period. Area planted to the crop during the subperiod witnessed an average annual growth rate of 4.41 percent. In the sub-period, 2011-2015, the growth rate of production witnessed a downward trend receding into a negative average annual growth of 1.88 percent. The decline in the domestic production of agricultural export commodities during the sub-period was due to inconsistent production patterns, problems of pests and diseases, low technology adoption, and ageing of trees (Nwachukwu et al 2011). Later, the production experienced a marginal growth rate of 0.25 per cent in the sub-period 2016-2018. Overall, for the entire period under review, 1980-2018, cashew nuts production in the country witnessed an annual average growth rate of 7.38 per cent suggesting that government programmes like structural adjustment programme put in place to diversify foreign exchange earnings and other policy reforms have yielded positive effect on the growth of cashew nuts production. Significant policy reforms include agricultural trade liberalization which led to abolition of marketing boards, thus, ensuring fair producer prices to farmers, the ban on importation of some agricultural commodities in order to encourage their domestic production, presidential initiatives on agricultural commodities, diversification of 
agricultural commodities, provision of incentives to farmers and agricultural export promotion (Federica et al, 2013, Ogunkola et al 2006, Alawode and Adeniranye,2020).

Table 2: Average Growth Rates of Nigerian Cashew Production.

\begin{tabular}{|c|c|c|c|c|c|c|c|c|c|}
\hline Period & $\begin{array}{c}1980- \\
85\end{array}$ & $\begin{array}{c}1986- \\
90\end{array}$ & $\begin{array}{c}\text { 1991- } \\
95\end{array}$ & $\begin{array}{l}1996- \\
2000\end{array}$ & $\begin{array}{l}2001- \\
2005\end{array}$ & $\begin{array}{l}2006- \\
2010\end{array}$ & $\begin{array}{l}2011- \\
2015\end{array}$ & $\begin{array}{l}2016- \\
2018\end{array}$ & 1980-2018 \\
\hline $\begin{array}{c}\text { Growth of } \\
\text { Area } \\
\text { Planted in } \\
\%\end{array}$ & 0.00 & 5.00 & 26.13 & 11.71 & 3.61 & 4.41 & -17.66 & -17.57 & 3.18 \\
\hline $\begin{array}{c}\text { Growth } \\
\text { Rate of } \\
\text { Yield of } \\
\text { Cashew in } \\
\%\end{array}$ & 0.00 & -0.80 & 0.44 & 37.78 & 1.34 & 1.61 & -18.20 & 39.47 & 6.03 \\
\hline $\begin{array}{l}\text { Growth } \\
\text { Rate of } \\
\text { Output in } \\
\%\end{array}$ & 0.00 & 4.00 & 26.74 & 47.42 & 4.99 & 6.12 & -1.88 & 0.25 & 7.38 \\
\hline
\end{tabular}

Source: Author's Estimates based on Data Extracted from FAOSTAT.

\subsection{Trend in the Nigerian Export Quantity and Export Value of Cashew Nuts}

The result in table 3 shows the growth in the export quantity and export value of cashew nuts from Nigeria. The highest average annual growth rate, in export quantity of cashew nuts, being 226 per cent, was attained in 1986-90 sub-period. The overwhelming increase observed in the export quantity of cashew nuts over this period can be attributed to the effect of Structural Adjustment Programme (SAP) between 1985 and 1989 which significantly reduced importation of agricultural items as well as diversification away from crude oil as the major export product and priority attention given to agricultural exports. Also, the export revenue which was derived from cashew exports witnessed significant increase in growth rate during the same 1986-1990 sub-period, suggesting a favourable price received for the export of cashew nuts as a result of devaluation of exchange rate at the implementation of SAP. The highest growth rate, 559.19 percent, in the export value of cashew nuts was recorded in the 2011-2015 subperiod. This can be attributed to the significant rise in the world market price which encouraged significant 
Volume: 06, Issue: 06 "November-December 2020"

growth rate in the export quantity of cashew nuts, (166 per cent), during this same sub-period. The lowest annual growth rate, -15.36 per cent, in cashew nuts export quantity was recorded in 1980-85 sub-period. This can be attributed to the unfavourable tax imposed on agricultural exports before the liberalization of trade.

Table 3: Average Growth Rates of Nigerian Cashew Production and Export.

\begin{tabular}{|c|c|c|c|c|c|c|c|c|c|}
\hline Period & $\begin{array}{c}1980- \\
85\end{array}$ & $1986-90$ & $\begin{array}{c}\text { 1991- } \\
95\end{array}$ & $\begin{array}{l}1996- \\
2000\end{array}$ & $\begin{array}{c}2001- \\
2005\end{array}$ & $\begin{array}{c}2006- \\
2010\end{array}$ & $\begin{array}{l}2011- \\
2015\end{array}$ & $\begin{array}{c}2016- \\
2018\end{array}$ & $\begin{array}{c}1980- \\
2018\end{array}$ \\
\hline $\begin{array}{l}\text { Growth } \\
\text { of Export } \\
\text { Quantity } \\
\text { in \% }\end{array}$ & -15.36 & 225.95 & 4.80 & 35.19 & 69.15 & -10.39 & 166.06 & 15.23 & 63.75 \\
\hline $\begin{array}{c}\text { Growth } \\
\text { of Export } \\
\text { Value in } \\
\%\end{array}$ & -7.39 & 227.44 & 20.73 & 54.52 & 58.25 & -9.25 & 559.19 & 180.87 & 133.16 \\
\hline
\end{tabular}

\section{Source: Author's Estimates based on Data Extracted from FAOSTAT.}

\subsection{Revealed Competitive Advantage of Cashew Exports.}

The results in table 4 shed some light on the trend and degree of instability in the estimated revealed competitive advantage for cashew exports in the world market. The variability is measured in terms of coefficient of variation $(\mathrm{CV})$. It shows the average percentage variation in either direction from the mean value from one year to the next. A coefficient of zero per cent depicts perfect stability and the higher it is from zero, the higher is the degree of instability. The table showed the mean value and variability of revealed competitive advantages of cashew nuts, over the period under review. As shown by the table, the revealed competitive advantage of cashew export rose from an annual average of I.87 in 1981-1985 sub-period, to 25.52 in 19861990 sub-period, thereafter it declined to annual average of 5.89 over 2006-2010 sub-period. Figure 2 also demonstrate the annual fluctuation in the revealed competitive advantage of cashew nut exports in the global market. 
International Journal of Agriculture and Environmental Research

ISSN: 2455-6939

Volume: 06, Issue: 06 "November-December 2020"

Table 4: Mean and Variability in Revealed Competitive Advantage of Cashew Export, in the World Market, 1980-2017.

\begin{tabular}{llll}
\hline Period & Mean & Standard Deviation & Coefficient of Variation \\
\hline $1981-85$ & 1.87 & 1.29 & 69.08 \\
$1986-90$ & 25.52 & 13.47 & 52.80 \\
$1991-95$ & 23.03 & 6.75 & 29.28 \\
$1996-2000$ & 23.03 & 15.21 & 66.06 \\
$2001-2005$ & 9.79 & 4.90 & 50.03 \\
$2006-2010$ & 5.89 & 2.39 & 40.58 \\
$2011-2017$ & 19.27 & 26.45 & 137.26 \\
\hline
\end{tabular}

Source: Author's Estimation.

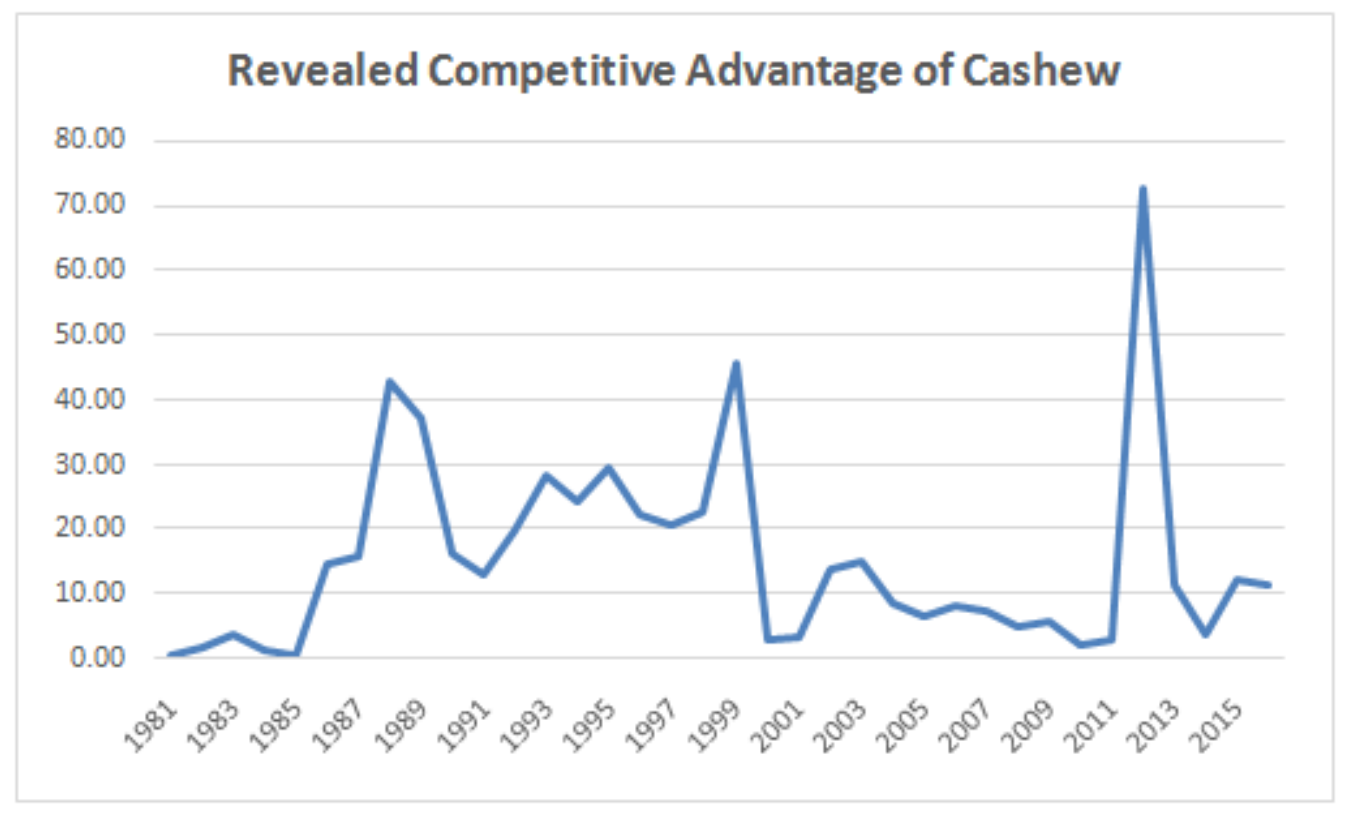

Source: Author's Estimation.

Figure 2: Line graph of Revealed Competitive Advantage of Cashew Exports.

Degree of instability in revealed competitive advantage of cashew, is revealed by the graph in figure 1 and the coefficient of variation in table 4 . The instability is very high, more than 28 percent, over the past three and a half decades. The competitiveness of cashew exports witnessed 
International Journal of Agriculture and Environmental Research

ISSN: 2455-6939

Volume: 06, Issue: 06 "November-December 2020"

high instability ranging from about 29 per cent in 1991-1995 sub-period to 137 per cent in 20112017 sub-period. The lowest average annual competitive advantage of cashew exports in the global market was 1.87 which was observed in the sub-period between 1981 and 1985 with the coefficient of variation of 69.08 per cent. The highest average annual competitive advantage for cashew exports was 25.52. This was observed in the sub-period between 1986 and 1990 with coefficient of variation of 52.08 per cent. There are pertinent significant factors that determine the nature of the competitiveness of cashew exports in the global market. It is imperative here to characterize the pattern of behaviour of the factors in the following section. Thereafter the nature of the effects of the factors will be discussed.

\subsection{Factors Influencing the Competitiveness of Nigerian Cashew Nuts in the World market.}

A continuous increase in cashew production will depend on the international competitiveness and the effects of the variables that significantly determined the competitiveness. Some important factors that influence competitiveness of Nigerian Cashew nuts in the World Market are proportion of agricultural researchers with MSc and Ph.D. degrees, investment in road construction and maintenance, electricity consumption per capita, and world market price of cashew nuts. The trends of these variables are briefly described as follows.

\subsubsection{World Market Price of Cashew Nuts.}

A crash in cashew price in the global market has forced many exporters to hold excess stocks of cashew nuts for the stocks to be bought at a time when prices become more favourable (Alawode and Adeniranye, 2020). Price sinking of cashew nuts gives rise to a supply glut in producing countries like Nigeria due to low processing. This implies that the lower the price in the global market, the lower will be the export supply of cashew in the world market by the Nigerian exporters. As shown by the result in table 5, the global market price of cashew is unstable as demonstrated by the coefficient of variation that ranged from the lowest of 2.05 per cent in the 1996-2000 subperiod to the highest of 25.72 per cent in the 1980-85 sub-period. Instability in the world market price of the product is also demonstrated by the line graphs in figures 3 and 4 . As shown in table5, the lowest average price of the product in the global market was US $\$ 634.86$ per metric tonne in the sub-period 2001-2005, while the highest average annual price of the product was US\$1,249.05 in the sub-period 2011-2017. Marketing of cashew nut is mostly affected by price instability due to seasonality of its production and lack of storage and processing facilities in Nigeria (Adejo et all, 2011).In this regard, a controllable pricing system for efficient and effective marketing can be ensured by proper storage and consistent supply of cashew nut in order to keep the market active throughout the year. 
International Journal of Agriculture and Environmental Research

ISSN: 2455-6939

Volume: 06, Issue: 06 "November-December 2020"

Table 5: Instability in World market price of Cashew Nuts.

\begin{tabular}{cccc}
\hline Period & $\begin{array}{c}\text { Mean in US\$ } \\
\text { per tonne }\end{array}$ & $\begin{array}{c}\text { Standard } \\
\text { Deviation. in } \\
\text { US\$ per tonne }\end{array}$ & Coefficient of Variation in \% \\
\hline $1980-85$ & 866.28 & 222.83 & 25.72 \\
$1986-90$ & 805.69 & 88.70 & 11.01 \\
$1991-95$ & 869.93 & 41.91 & 4.82 \\
$1996-2000$ & 900.33 & 18.45 & 2.05 \\
$2001-2005$ & 634.86 & 70.07 & 11.04 \\
$2006-2010$ & 644.75 & 101.59 & 15.76 \\
$2011-2017$ & 1249.05 & 296.29 & 23.72 \\
\hline
\end{tabular}

Source: Underlying data collected from FAOSTAT.

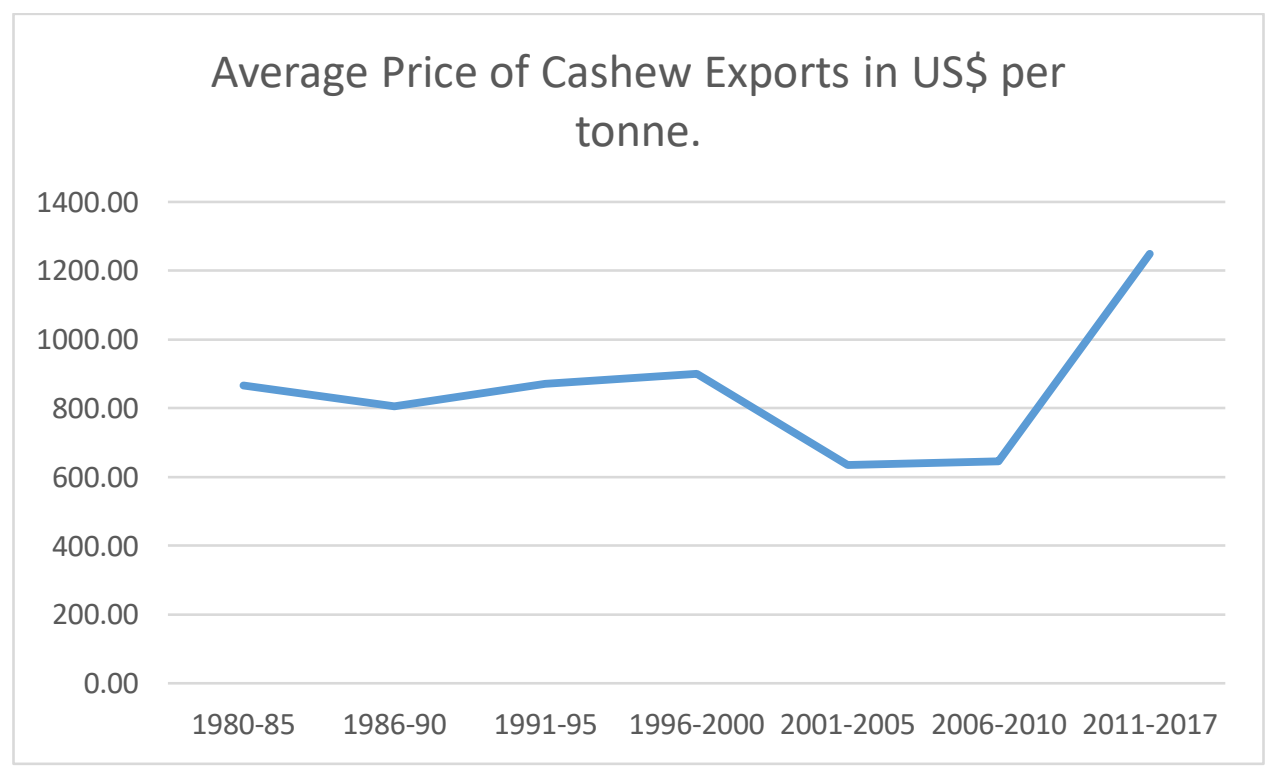

Source: Underlying data extracted from FAOSTAT, 2020.

Figure 3: Line Graph of Average Price of Cashew Exports in the Global Market. 
International Journal of Agriculture and Environmental Research

ISSN: 2455-6939

Volume: 06, Issue: 06 "November-December 2020"

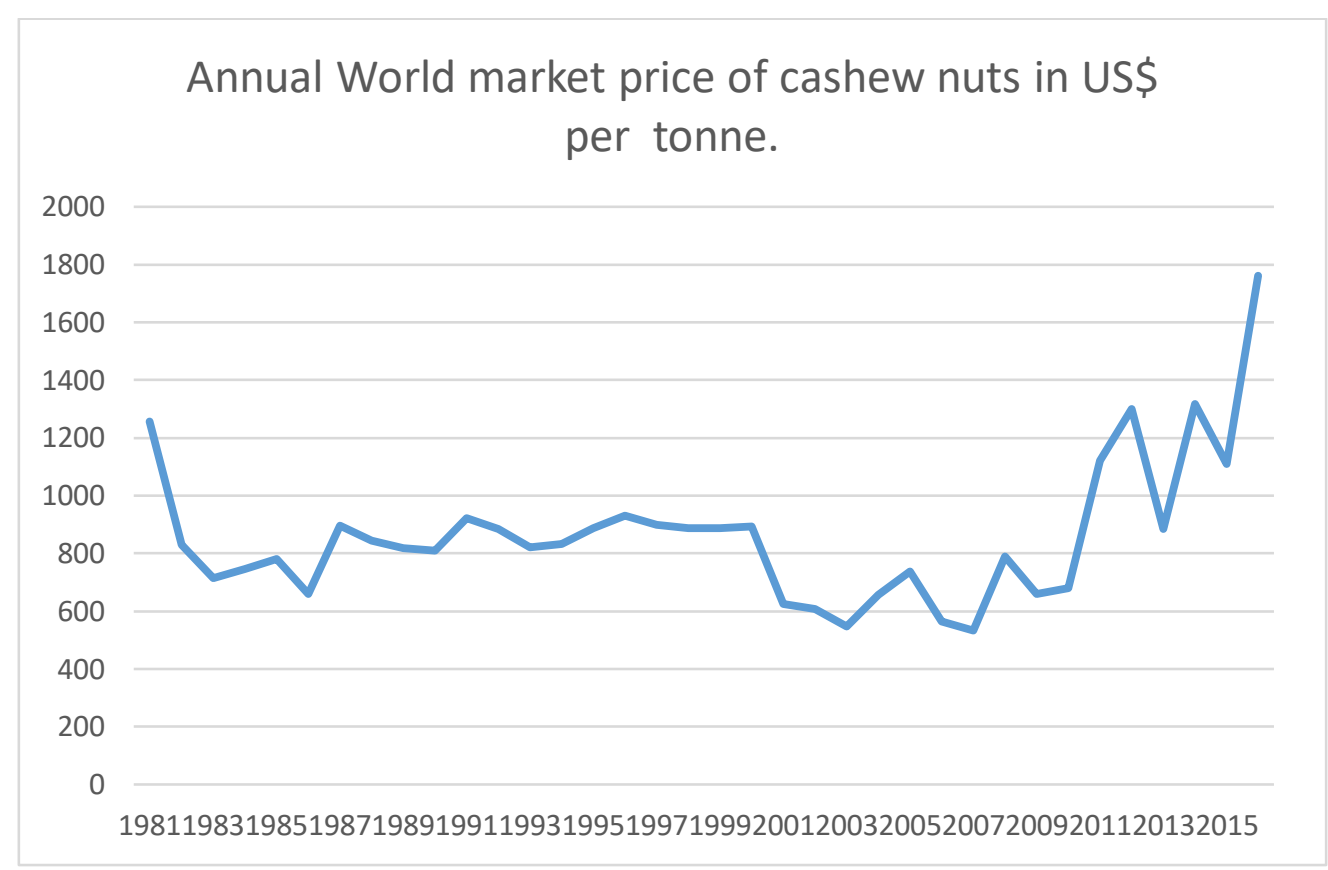

Source: FAOSTAT, 2020.

Figure 4: Line graph of annual world market price of cashew.

\subsubsection{Agricultural Researchers with Higher Education.}

Agricultural researchers are necessary for the purpose of building up technology capabilities that will generate innovations and improved yield variety as well as new branding and packaging for accessing the global market. This will also determine the number of agricultural researchers per farmers which is very low in Nigeria. Table 6 revealed that the total agricultural researchers with higher education, that is those possessing MSc and Ph.D. degrees remained lower than 42 per cent over the entire period under review. Instability in the proportion of highly educated Agricultural Researchers is moderate as shown by the coefficient of variation that varied from the lowest of 1.96 per cent in the sub-period 2011-2017 to the highest of 22.97 per cent in 198090 sub-period.

\subsubsection{Investment in Road Infrastructure and Electricity Consumption Per Capita.}

Investment in road and transport infrastructure is important to induce market connectivity and competitiveness of Nigerian exports. As shown in table 6, the level of investment in road construction and maintenance is still low in Nigeria. Investment in the combination of road, transport and communication infrastructure in Nigeria accounts for only 1.19 per cent of Gross Domestic Product (GDP), over 1981-1990 sub-period and this further declined to 0.44 per cent of GDP during 2011-2016 sub-period, averaging 0.93 per cent over the past three and a half 
decades. When compared to China, infrastructure investment was an average of 7.78 per cent of China's GDP, and this spurred a large part of China's industrial growth (Claudia, 2017). Only 30 percent of the rural population in Nigeria has access to all-weather roads (Fungo et al 2017). Poor road which results into high transport cost is a missing link in the transport network in Nigeria. This poses a challenge to market integration and international trade. Trade costs in Nigeria, according to Atkin and Donaldson, 2015 are four to five times larger than that in the United States. Further, table6 revealed low per capita consumption of public electric power. This heightens the cost of industrial processing of cashew nuts thus constraining value addition to the raw cashew nuts, which in turn can adversely affect the competitiveness of the product in the global market.

Table 6: Agricultural Researchers with Higher Education, Road Infrastructure and Per Capita Electricity Consumption in Nigeria, 1980-2017

\begin{tabular}{lllll}
\hline & $1980-90$ & $1991-$ & $2001-$ & $2011-$ \\
& & 2000 & 2010 & 2017 \\
\hline $\begin{array}{l}\text { Agricultural Researchers with MSc and Ph.D. as a } \\
\text { share of total }\end{array}$ & & & & \\
Mean & 22.21 & 34.19 & 39.86 & 41.61 \\
Std Dev. & 5.1 & 2.16 & 1.21 & 0.82 \\
Coefficient of Variation & 22.97 & 6.32 & 3.02 & 1.96 \\
& & & & \\
& & & & \\
Road Construction and Maintenance in million & & & & \\
US\$ & & & & \\
Mean & 125.89 & 220.11 & 1145.35 & 1587.78 \\
Std Dev & 38.53 & 390.83 & 961.13 & 740.54 \\
Coefficient of Variation & 30.61 & 177.56 & 83.92 & 46.64
\end{tabular}

Electricity consumption per capita in kilowatt hour per capita

Mean

$80.85 \quad 86.27 \quad 117.01$

147.99 
International Journal of Agriculture and Environmental Research

ISSN: 2455-6939

Volume: 06, Issue: 06 "November-December 2020"

Std Dev

14.01

8.86

19.13

5.03

Coefficient of Variation

$17.32 \quad 10.27$

16.35

3.4

Source: Author's estimation based on Data collected from ASTI and World Development Indicators.

\subsection{Determinants of Competitiveness of Nigerian Cashew Exports.}

Estimated parameters and the related statistical test results of the determinants of revealed competitive advantage of cashew nuts are shown in Table7. As shown in the Table, the result is a good fit of the data as stability of estimated model was established by outcome of Cusum test. Also, serial correlation test confirmed absence of serial correlation among the variables. Adjusted $\mathrm{R}^{2}$ indicates that the independent variables explained 62 per cent of variation in revealed competitive advantage of cashew nut export. As shown in the table, four variables were significant determinants of competitiveness of cashew nut export. These are proportion of agricultural researchers with MSc and Ph.D. degrees, investment in road construction and maintenance, electricity consumption per capita, and world market price of cashew nuts. The coefficients of the variables have the expected signs and they are statistically significant at 5 per cent or less.

Table 7: Long Run Model Estimated for Revealed Competitive Advantage of Cashew nuts

Dependent Variable: D (LOGRCACA) = D (Log of Revealed Competitive Advantage of Cashew.

\begin{tabular}{llll}
\hline Explanatory Variable & Coefficient & t-Statistic & Prob. \\
\hline C & -0.188505 & -0.970448 & 0.3419 \\
D(LOGRCACA(-1)) & 0.037111 & 0.277655 & 0.7838 \\
D(LOGFDIA(-1)) & 0.212464 & 1.626802 & 0.1174 \\
D(LOGGFCFAGRIC(-1)) & -0.257183 & -1.536203 & 0.1381 \\
D(LOGTAGRHEDU(-1)) & $1.908268 * *$ & 2.416106 & 0.024 \\
D(LOGEXCHR(-1)) & -0.608616 & -0.968253 & 0.343 \\
D(LOGINFRAROAD(-1)) & $0.48302 * *$ & 2.359783 & 0.0271 \\
D(LOGECKWHPC $(-1))$ & $1.397927 * * *$ & 3.729618 & 0.0011 \\
D (LOGWPCA $(-1))$ & $1.229014 * * *$ & 3.661314 & 0.0013
\end{tabular}


International Journal of Agriculture and Environmental Research

ISSN: 2455-6939

Volume: 06, Issue: 06 "November-December 2020"
D(LOGLINTR(-1))
0.068702
0.067056
0.9471

R-squared

0.733442

Adjusted R-squared

0.617547

Durbin-Watson stat

1.666594

**means significant at 5percent

*** means significant at 1 per cent.

Source: Author's Estimation.

The estimated coefficient of the variable for the proportion of agricultural researchers with higher degrees (TAGRHEDU) indicates a positive effect on the competitiveness of cashew nuts export. The magnitude of the coefficient revealed that a $10 \%$ increase in the proportion of agricultural researchers with higher degree will bring about 19 per cent increase in the revealed competitive advantage of cashew nuts export (RCACA). This is consistent with the theoretical expectations of Porter's Diamond Model. Agricultural researchers could generate new information about new market opportunities. Such information could play significant role in the process of innovation and improvement. They can also generate improved and high yielding variety of cashew that will improve productivity per labour and per hectare of land. Higher productivity will reduce production cost which can make the product more competitive in the global market.

The coefficient of the variable on government investment on road construction and maintenance (INFRAROAD) is positive and significant at $1 \%$. The positive sign indicates that effectiveness in increasing road construction and maintenance will induce an increase in competitiveness of cashew nuts export. The magnitude of the coefficient, 0.48 , suggests that a 10 per cent increase in road construction and maintenance of old damaged roads will lead to $4.8 \%$ increase in the revealed competitive advantage of cashew nuts export. This is plausible when the good road network facilitates connectivity and linkage with farmers for the use of high productivity technology and movement of agricultural inputs from the urban market to the farm as well as movement of primary agricultural produce to processing firms for increased value addition.

Similarly, the coefficient of per capita consumption of electricity (ECKWHPC) is positive and significant at one per cent indicating that increase in electricity consumption will induce an increase in revealed competitive advantage of cashew nut export. The magnitude of the coefficient, 1.39 , shows that a $10 \%$ increase in electric power consumption per capita will lead to $13.9 \%$ increase in the competitiveness of cashew nut export. Also, world market price of cashew nuts (WPCA) impacts positively on the competitiveness of cashew nut export as shown by the positive sign of the variable. The estimated coefficient of the variable, 1.22 is significant at $1 \%$. The magnitude of the coefficient implies that a $10 \%$ increase in world market price will induce 
International Journal of Agriculture and Environmental Research

ISSN: 2455-6939

Volume: 06, Issue: 06 "November-December 2020"

12.2\% increase in the revealed competitive advantage of cashew nut export. Increasing world market price is an incentive for increased production and supply of cashew nuts in the world market.

\subsection{RECOMMENDATIONS AND CONCLUSIONS.}

Major findings indicate four explanatory variables significantly determined the competitiveness of cashew nut export. These are proportion of agricultural researchers with MSc and Ph.D. degrees, investment in road construction and maintenance, electricity consumption per capita, and world market price of cashew nuts. All the variables have positive effects on the competitiveness of cashew nuts exports. They jointly explained 62 per cent of variation in the revealed competitive advantage of cashew nuts. On the basis of the findings, the following recommendations should be given priority attention so as to improve on the competitiveness of Nigerian cashew exports in the global market.

I. Agricultural Research institutes in Nigeria should be supported with state-of-the-art research equipment and adequate funding and they should conduct research that will generate commercialized scientific breakthroughs, new agricultural innovations and products of higher grade to meet international standards.

II. Research, extension and farmers linkage should be strengthened with adequate logistics facilities that will induce easy contacts with actors in the cashew value chain and enhance the uptake of high productivity technology.

III. Improvement of industrial activities will depend on the extent to which infrastructure investment is well targeted. Efficiency in spending on infrastructure should be geared towards improving electricity consumption, transportation system and repair of old damaged roads and build new ones that will link village to village and village to industrial centres, as well as linkage of urban towns and ports. Improving per capita consumption of public electricity will induce improved processing and value addition to raw cashew nuts for increased exports of the transformed products of cashew nuts.

\section{REFERENCES}

Adeigbe O. O., Olasupo F. O., Adewale B. D. and Muyiwa A. A. (2015). A Review on Cashew Research and Production in Nigeria in The Last Four Decades. Scientific Journals and essays. Academic Journals. Volume 10(5), pp196-209.

Adejo P.E., J.O. Otitolayeand U. Onuche (2011). Analysis of Marketing Channel and Pricing System of Cashewnuts in the North Central of Nigeria.Journal of Agricultural Science. Volume 3, No 3. www.ccsenet.org/jas 
International Journal of Agriculture and Environmental Research

ISSN: 2455-6939

Volume: 06, Issue: 06 "November-December 2020"

Alawode O.O. and A.V. Adeniranye (2020). Competitiveness of Nigerian Cashew Nuts in the Global Market 1961-2016: An Application of Vector Error Correction Model (VECM). International Journal of Innovative Development and Policy Studies 8(1): 46-57. SEAHI Publication www.seahipaj.org

Atkin and Donaldson, 2015: Who is getting globalized? The Size and Implications of International trade Costs. No w21439. Cambridge National Bureau of Economic Research.

Ayoola G.B. (2018): Essays on Agricultural Economy. Nonexperimental Writings on Agricultural Policy and Development Administration in Nigeria.

CBN. Annual Report and Statement of Accounts. Central Bank of Nigeria, Abuja. Various Years.

Chemonics International (2002): Subsector Assessment of the Nigerian Cashew Industry. USAID, Nigeria.

Claudia et al 2017: Transport policies and Development. The Journal of Development Studies. Volume 53, No 4 page 465-480.

Food and Agriculture Organisation. www.faostat.org accessed 2020.

Federica, A.J., Helene, B.G., Alban,M.A. and Megan,W.(22013). Monitoring and Analysing Food and Agricultural policies in Africa. Synthesis report 2013. Food and Agriculture Organisation of the United Nations, Rome,2013.

Fungo, E.; Krygsman, S.; Nel, H.(2017): The role of road infrastructure in agricultural productionPapers presented at the 36th Southern African Transport Conference, CSIR International Convention Centre, Pretoria, South Africa on 10-13 July 2017.

Gonul M and Yusuf M (2016): Determinants of Export Competitiveness. Evidence from OECD Manufacturing. Journal of Economics and Political Economy. Volume3 Issue1.

Olawale Mashood and Lateef Akinkunle (2018). Nigerian Cashew Economy: A Review of Nut Production Sector.

Ogunkola, E.O., Bankole, A.S. and Adewuyi, A.O. (2006). An Evaluation of the Impact of Nigeria's Trade and Investment Policy Reforms. Trade Policy Research and Training Programme. Ibadan, Nigeria, Department of Economics, University of Ibadan.

Porter, M.E. (1998): The Competitive Advantage of Nations. Macmillan Business Review, p33. Porter, M (1990): The Competitive Advantage of Nations. Harvard Business Review, New York. 
Vollrath, T (1991): A Theoretical Evaluation of Alternative Trade Intensity Measure of Revealed Comparative Advantage. Review of World Economics, 127, 265-280.

Vollrath T (1987): Revealed Competitive Advantage for Wheat. International Economic Division, Economic Research Service, U.S. Department of Agriculture. Report No AGES861030.

World Bank (2005): Global Agricultural Trade and Developing Countries, World Bank. Washington DC.

Zhang, (2015): What Drives Export Competitiveness? The Role of FDI in Chinese Manufacturing. Contemporary Economic Policy, 33(3), 499-512. 